\title{
INVENTORY OF FORTS IN INDONESIA
}

\author{
N. Rinandi ${ }^{\mathrm{a}}$, F. Suryaningsih ${ }^{\mathrm{a}, *}$ \\ ${ }^{a}$ Documentation Center for Architecture Indonesia (Pusat Dokumentasi Arsitektur Indonesia), Jl. Tebet Dalam 4-i no.30, Jakarta \\ 12810, Indonesia - febrian25@gmail.com / pda.pusdokars@gmail.com
}

Commission B, WG B-4

KEY WORDS: Database, Forts, Indonesia, Inventory, Immovable Heritage, Defence, Colonial

\begin{abstract}
:
The great archipelago in Indonesia with its wealthy and various nature, the products and commodities of tropic agriculture and the rich soil, was through the centuries a region of interest for other countries all over the world. For several reasons some of these countries came to Indonesia to establish their existence and tried to monopolize the trading. These countries such as the Portuguese, the Spanish, the Dutch and the British built strengthened trade stations which later became forts all over Indonesia to defend their interest. The archipelago of Indonesia possesses a great number of fortification-works as legacies of native rulers and those which were built by European trading companies and later became colonial powers in the $16^{\text {th }}$ to the $19^{\text {th }}$ centuries. These legacies include those specific structures built as a defence system during pre and within the period of World War II. These fortresses are nowadaysvaluable subjects, because they might be considered as shared heritage among these countries and Indonesia. It's important to develop a vision to preserve these particular subjects of heritage, because they are an interesting part of the Indonesian history and its cultural treasures. The Government of the Republic of Indonesia has national program to compile a comprehensive documentation of the existing condition of these various types of forts as cultural heritage. The result of the 3 years project was a comprehensive 442 forts database in Indonesia, which will be very valuable to the implementation of legal protection, preservation matters and adaptive re-use in the future.
\end{abstract}

\section{INTRODUCTION}

\subsection{Project Background}

Indonesia has numerous forts (benteng, in Indonesian) not only as a legacy from the traditional or indigenous local culture but also as an inheritance from past cultural contacts between the native people and foreign nations. The earliest building constructed as a defence structure was built by the Portuguese and Spanish spice traders in the $16^{\text {th }}$ century, followed by the British and the Dutch up to $19^{\text {th }}$ century. The latest constructions were the bunkers and pillboxes built in the $20^{\text {th }}$ century by the Japanese and Allied army during the period of World War II.

Bearing in mind the significance of its authenticity and uniqueness these monuments from the past deserve to be preserved. Documenting is a first an initial step of the critical efforts to be undertaken. The content and quality of the documentation would be based on international standards, according to the law on Cultural Heritage. The result was a comprehensive database, which will be very valuable to the implementation of legal protection, preservation matters and adaptive re-use in the future.

The inventory project of Forts in Indonesia was initiated by the Ministry of Education of Culture of Republic Indonesia, by the Directorate of Cultural Heritage Preservation. The project was executed and coordinated by the Documentation Centre for Architecture Indonesia (Pusat Dokumentasi Arsitektur - PDA) in collaboration with PAC Architects and Consultant in Netherlands as counterpart. The project was funded by the
Ministry of Foreign Affairs of the Netherlands in collaboration with The Ministry of Education and Culture of Republic Indonesia. For this project a three-party Memorandum of Understanding was signed to establish a project of The Documentation and Identification of Forts in Indonesia, for a period of 3 years (2007-2010).

\subsection{Sustainability Value}

The outcome and result of the project was a tangible heritage inventory, based on field and archive research. The survey methodology, the transparency of the documents to deliver is a guarantee to the sustainability in using the material after the project is finished.

It is one of the assets of this project to provide the Government with the tools and possibilities to exercise implementation to the national law and to supply them authorized documentation material; which makes it possible to anticipate on coming conservation matters. For instance the decision to maintain the subject in the actual situation and protect it to changes or demolishing.

\subsection{Public Awareness and Community Base Involvement}

The project was intended to stimulate the public awareness, in this case, particular to architectural and urban heritage, to encourage the cooperation between the several involved parties as there are: the citizens (heritage movements)/ governmental agencies/ universities and other institutional organizations. In the project, PDA established a network between parties in the Indonesia region not only for the field survey but also to

* Corresponding author 
construct an inventory format that has agreed based on the consensus of the whole join parties. This scheme was effective not only to generate public awareness but also involving the community in the project to ensure its sustainability in the future.

\section{FORTS IN INDONESIA}

\subsection{Forts Classification}

History of Forts in Indonesia is chronologically divided into several periods, based on significant historical events that took place in Indonesia, especially pertaining to the construction of the forts.

1. Before 1512: prior to the arrival of Westerners

2. 1512: arrival of the Portuguese in Nusantara (the Archipelago)

3. 1799 : end of de Verenigde Oost-Indische Compagnie (VOC)

4. 1799-1942: The Netherlands Indies Period

5. 1942: the Japanese Occupation in Indonesia

6. 1945: Independence of Indonesia

Besides forts that were built in the Colonial era and during World War II, such as those encountered in East Indonesia, there were many forts discovered that can be classified as traditional forts and a number of city walls which were built during the Islam era and even in colonial era. The often overlapping information's pertaining to historical periods and nation developers pose quite a difficult problem.

In order to remain consistent as far as is possible, it has been decided to simplify the classification of forts below:

2.1.1. Nusantara Forts: Forts built by the Indonesian. This category consists of: simple traditional forts, kingdom forts and forts which were built by the Indonesian in their fight against colonialism during the colonial era.

2.1.2. Colonial Forts: Forts built during the time Indonesia was colonized by Western nations, were among other, forts built by the Spanish, Portuguese, British, and the Dutch.

2.1.3. Defence Structures of the World War: They are structures or defence structures built during World War I and II in Indonesia. This group includes defence structures that had been built by the Japanese, Dutch and the Allied Forces.

\begin{tabular}{|l|l|}
\hline $\begin{array}{l}\text { Nusantara } \\
\text { Fort }\end{array}$ & \begin{tabular}{ll|} 
City-Settlement Wall \\
\hline Colonial fort
\end{tabular} \\
\hline $\begin{array}{l}\text { World War II Defense } \\
\text { Structure }\end{array}$ & $\begin{array}{l}\text { Fort/ castle/ blockhouse/ redout/ } \\
\text { battery/ martello/ camp }\end{array}$ \\
\hline
\end{tabular}

Figure 1. Classification of forts

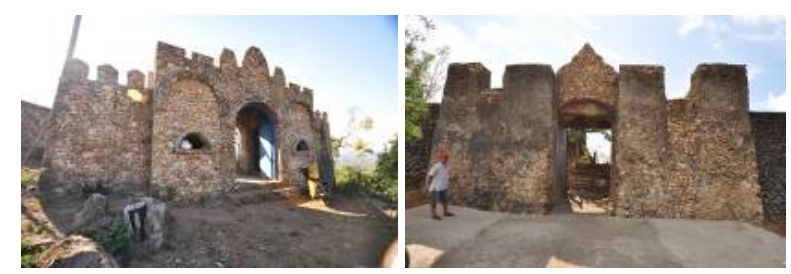

Figure 2. Fort Takimpo (left) and Fort Baadia (right) at Bau-bau Island, South-East Sulawesi, as sample of Nusantara forts (c) Image Copyright 2010, PDA
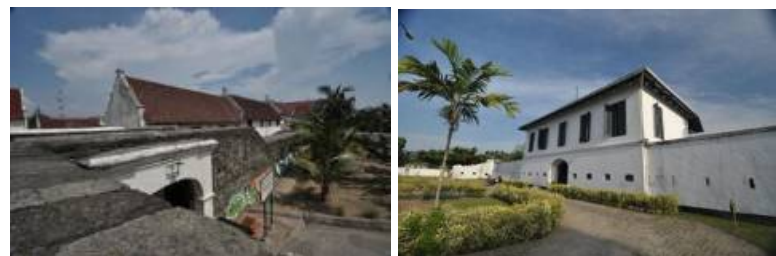

Figure 3. Fort Rotterdam (left) and Fort Balangnipa (right) at South Sulawesi as sample of Colonial forts (C) Image Copyright 2010, PDA

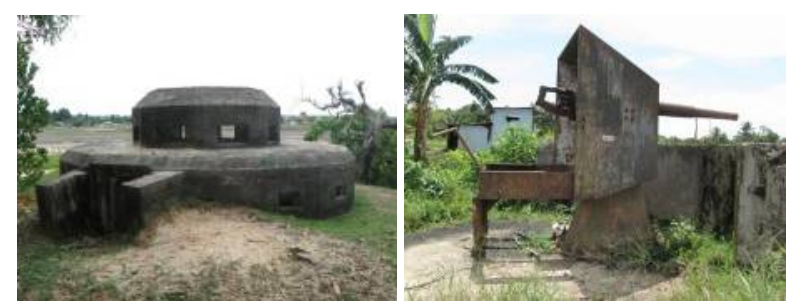

Figure 4. Pillbox (left) and defence structure (right) of World War II in Tarakan Island, North Kalimantan (C) Image Copyright 2010, PDA

\subsection{Forts in Indonesia Region}

Due to its broad boundary and its cross cutting and multidimension issues, the inventory of forts cannot be done at one time. Therefore, there is a need to divide the area of inventory into sustainable and integrated phases. The whole project takes 3 years and be dividing into three big stages and zones. Each stage was taking a year to be done.

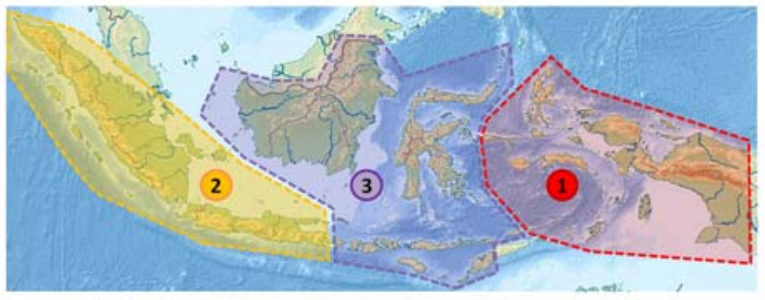

Figure 5. Regions divide in Indonesia for forts inventory project. Region 1 in year 1: East Indonesia; region 2 in year 2 West Indonesia; region 3 in year 3: Central Indonesia 


\section{INVENTORY METHODOLOGY}

\subsection{Preparation}

Before the project start, it is important to prepare not only the equipments but also the inventory format. PDA has managed a preparation works as follows:

3.1.1. Field Try-out: Conduct a field try-out for probing the questionnaire format: to be used for the survey.

3.1.2. Terms and types of forts: Determine the right names or technical terms for the types of defence work and its elements in the Indonesian language with reference to the terminology as used mainly in the Dutch or English language. Special consultation was made with The National Language Center and which agreed accepted specific terms about fort architecture were proposed to be included in the Great Dictionary of Bahasa Indonesia.

3.1.3. Draft the Format, System and Software: Draft the format and items to be included and listed in the questionnaire for the survey and how the acquired data to be tabulated and be further processed to become a format for a catalogue and website data in the national information system. The format should be tried out and enhanced in every phase.

As mentioned before, this project was executed in cooperation with various institutions and communities, the choice of system and software become a critical subject. Considering that many institutions and communities in remote areas might be not have a supporting advance software, as a coordinator PDA decide to use basic software as Microsoft Excel and Microsoft Access to establish the database in a uniform software that could be easy accessible in any regions.

3.1.4. Forts classification: Decide a classification of the fort types.

3.1.5. Regular Evaluation: Organize a midyear evaluation and a year evaluation in which during the events supporting activities were arranged such as the publication of necessary reports, a display of exhibition, a presentation of a special produced film documentary, and a scientific appraisal meeting to evaluate each phase achievements.

3.1.6. Regular Data Verification: The results of draft database should be verified by expert team to make sure its quality and accuracy.

3.1.7. Data backup and publication: The final database in Microsoft Access will be backup in master web as part of the system of web site that could accessible for public in certain specific settings.

\subsection{Data Collecting System}

Basically, the inventory activity comprises a number of principal works consisting of field surveys and data collecting, making maps, sketches and photos and video recordings, literature and archives study in Indonesia and Netherlands was pertaining to the historical aspects, and data inputting into a comprehensive database.

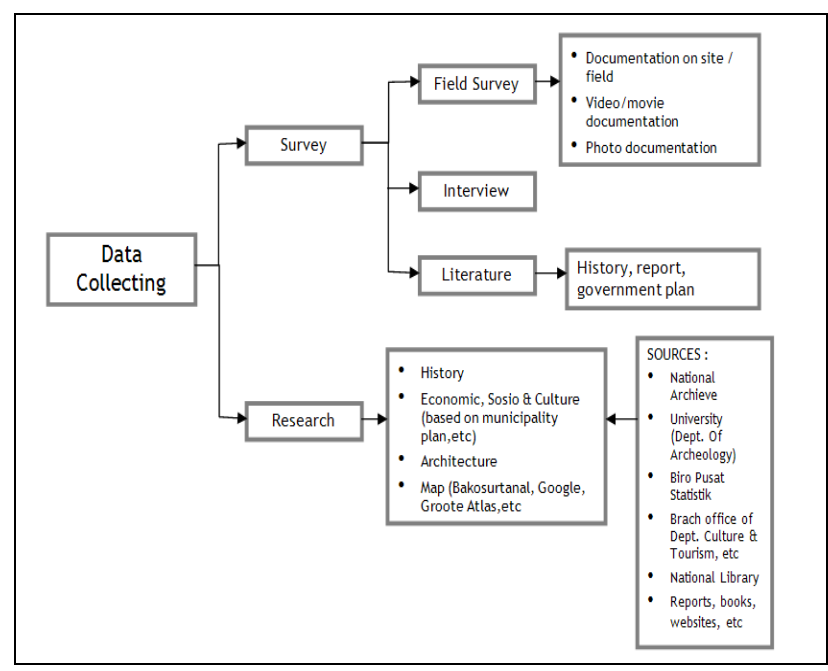

Figure 6. Data collecting system

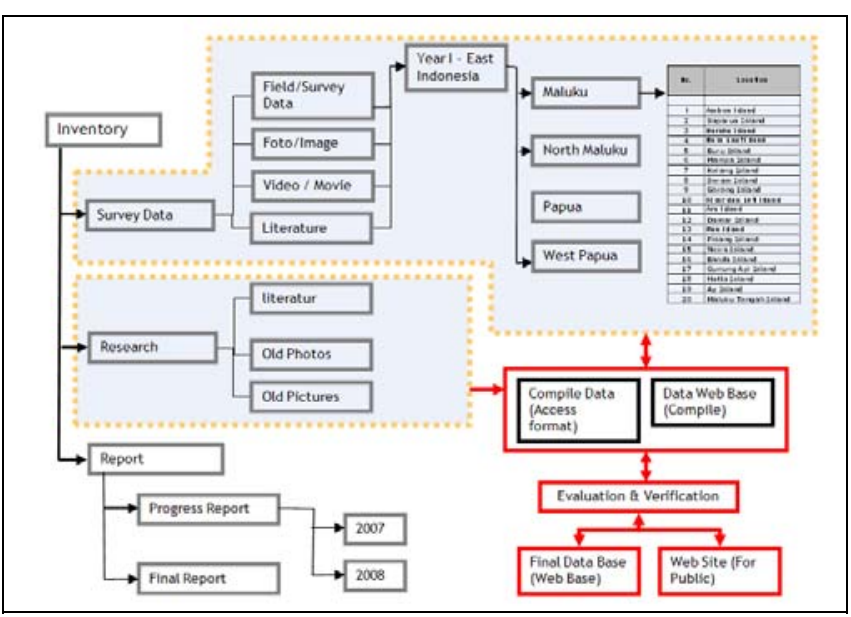

Figure 7. Model of data collecting system

\subsection{Inventory and Database Structure}

During the 3 years project, the data structure was developed and upgraded based on the agreement and consensus between stakeholders (communities, governments and experts).

\subsubsection{Data Structure}

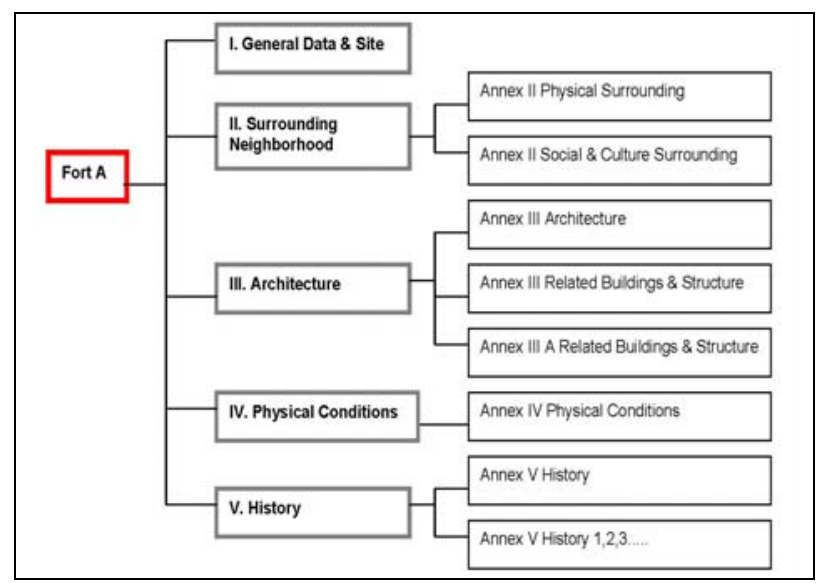

Figure 8. Main data structure 


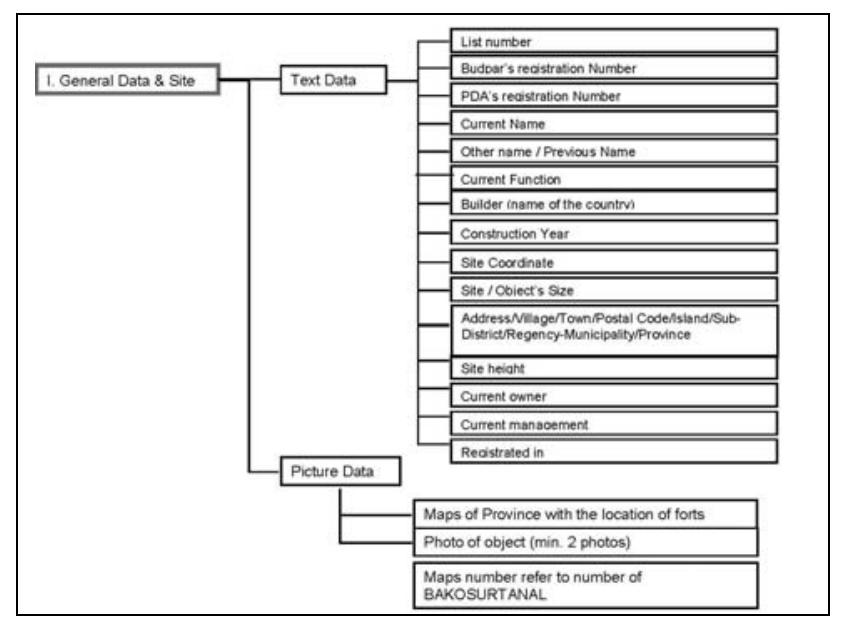

Figure 9. Data structure of general and site

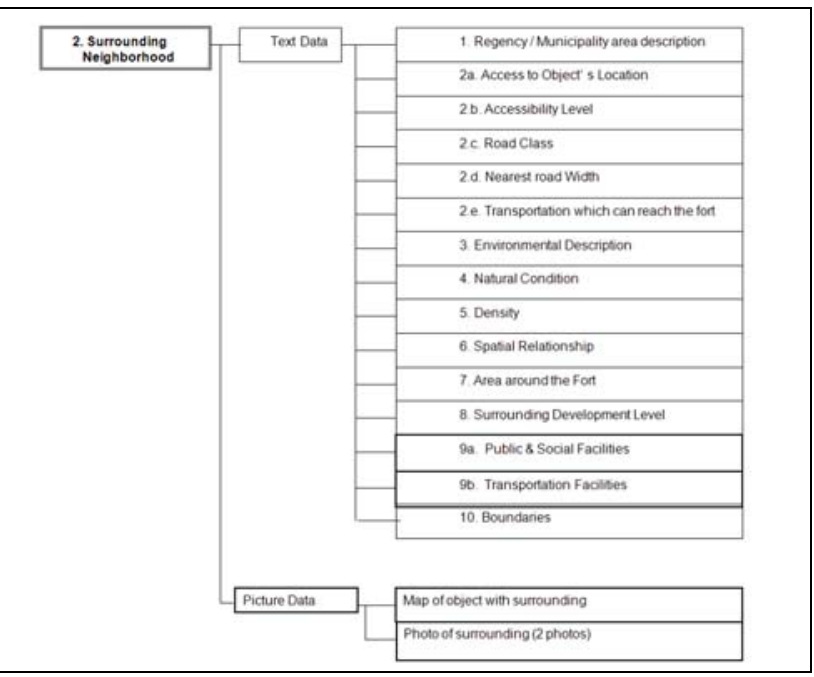

Figure 10. Data structure of surrounding neighbourhood

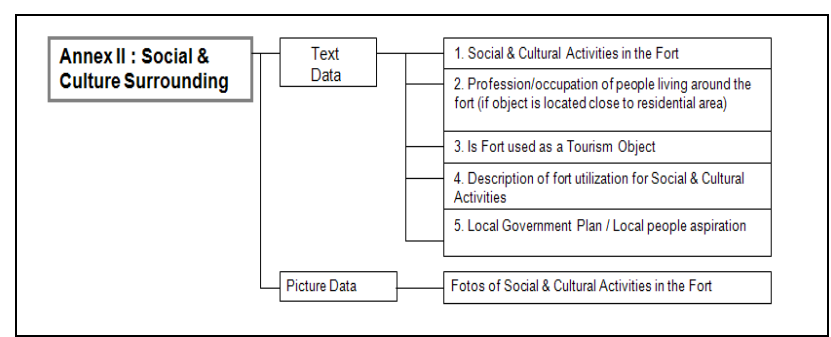

Figure 11. Annex II: Data structure of social and culture surrounding

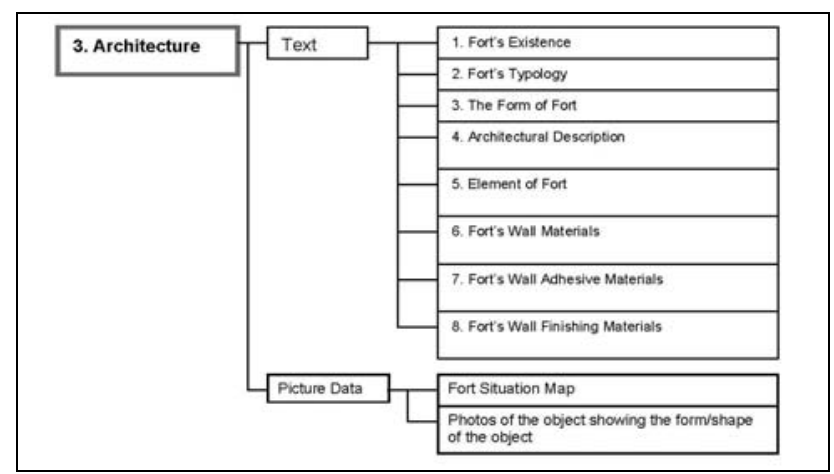

Figure 12. Architecture data structure

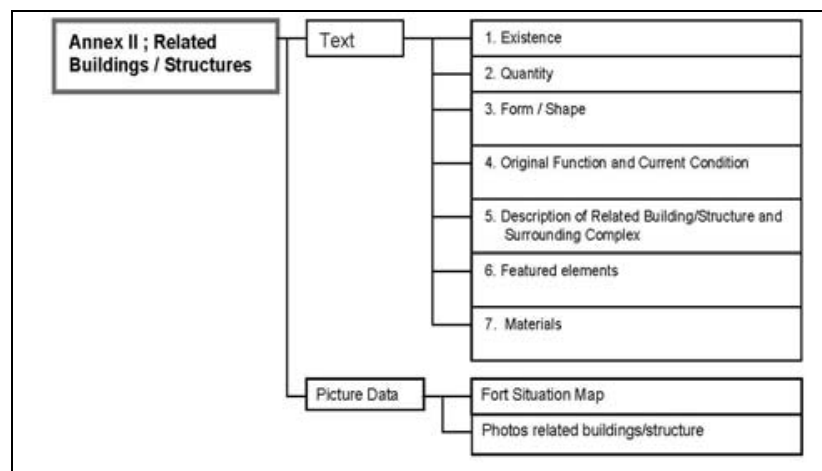

Figure 13. Annex II: Data structure of related buildings/structure

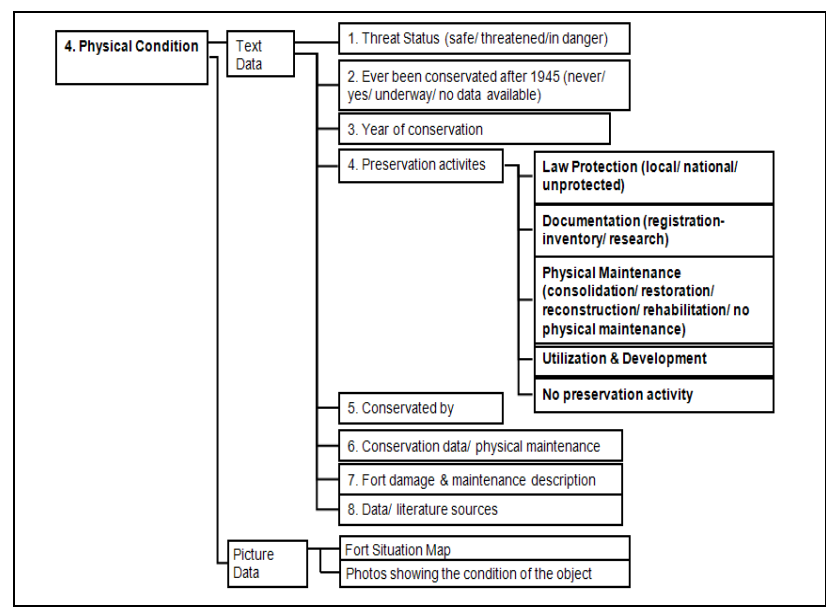

Figure 14. Data structure of physical condition

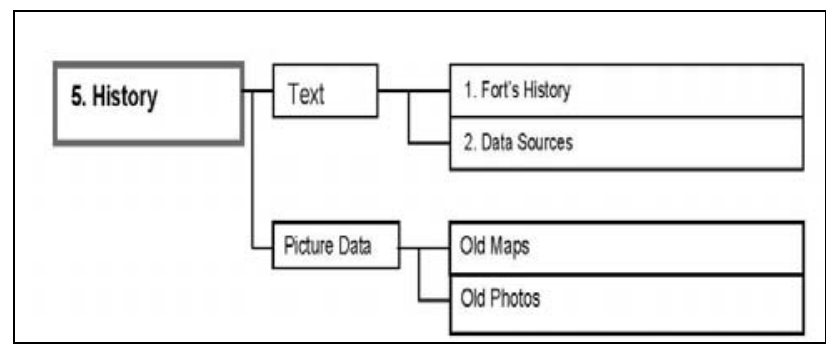

Figure 15. Data structure of history

\subsubsection{Code and numbering}

The code number system for PDA's number is according to the Universal Decimal Classification (UDC). The division is based on type or building function. The inventory is not only found forts but also other type of building. Some of the objects are related to the forts. 


\begin{tabular}{|l|l|l|l|}
\hline No. & $\begin{array}{l}\text { Structure/building } \\
\text { type/function }\end{array}$ & $\begin{array}{l}\text { Code } \\
\text { Number }\end{array}$ & $\begin{array}{l}\text { Characters } \\
\text { code }\end{array}$ \\
\hline 1. & Fort & 623.1 & $\mathrm{btg}$ \\
\hline 2. & $\begin{array}{l}\text { Defence works / } \\
\text { structure }\end{array}$ & 623.3 & $\mathrm{sp}$ \\
\hline 3. & $\begin{array}{l}\text { Military } \\
\text { base/depots/barrack } \\
\text { s }\end{array}$ & 725.18 & $\mathrm{~mm}$ \\
\hline 4. & Lodge & 634.31 & $\mathrm{lj}$ \\
\hline 5. & Perk & 631.27 & $\mathrm{prk}$ \\
\hline 6. & Monument / Statue & 725.94 & tg \\
\hline 7. & Hospital & 725.5 & $\mathrm{rs}$ \\
\hline
\end{tabular}

Table 16. Table of code number and characters based on building types and function

PDA code number also refers to list number of province, regency/municipality based on Department Internal Affairs. The number of municipality will following by list number of island. Number of island based on alphabetical order. The code number of PDA will be written in following: UDCnumber/Province number/Regency number/Island number/Fort number. For example look at this table below:

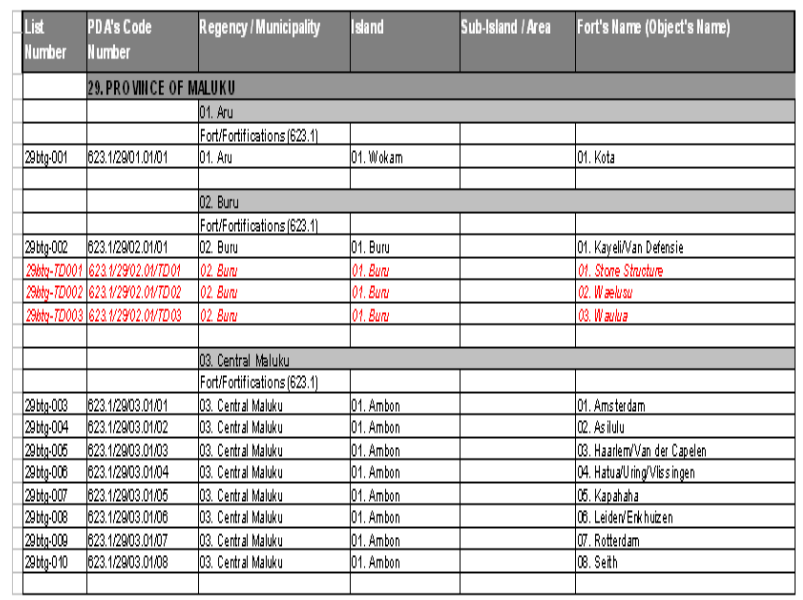

Table 17. Sample of forts list and its code numbering system in Microsoft Excel file

Fort Amsterdam (fort code 623.1), at Maluku Province (no.29), Regency of Central Maluku (no.03), at Ambon's island (no.01). Fort Amsterdam is no.001 fort in Ambon's island, based on alphabetical order. So, the PDA code number of fort Amsterdam will be written: 623.1/29/03.01/001. The list number shows the number and amount of each object (refer to the type of building/structure-look at character code). The list number will be written as follows: number of province/building type-list number (based on list number of each type). For example fort Amsterdam, it will be written: 29btg-001.

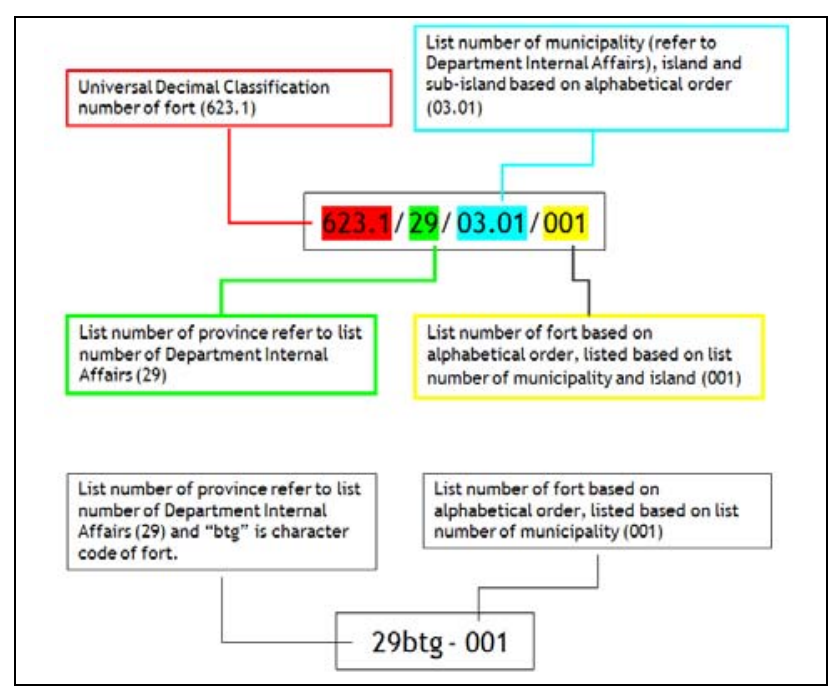

Figure 18. Code numbering of forts

\subsubsection{Objects evaluation reference}

It is needed to get information of forts intact condition. PDA has made reference for the surveyors from various education backgrounds to make same evaluation judgment.

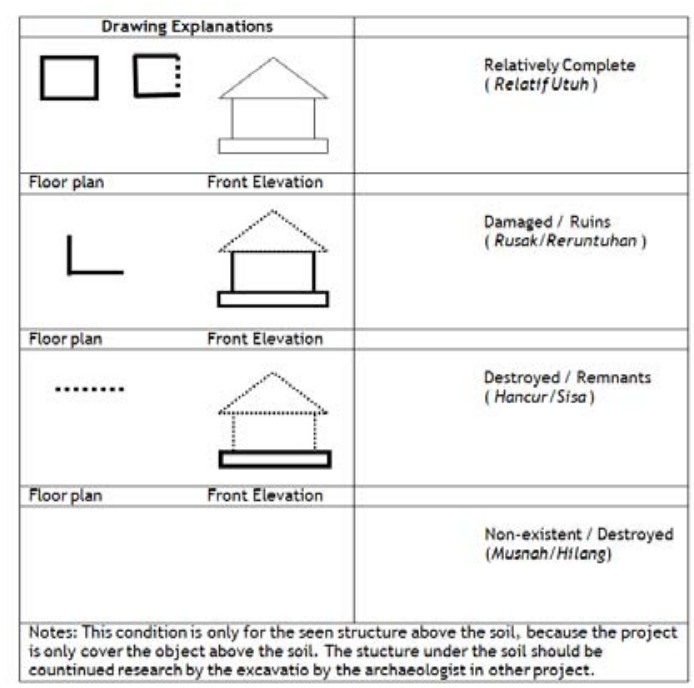

Table 19. Table of objects evaluation reference

\subsubsection{Inventory Format and Layout}

Refer to the data structure, the inventory format and layout was designed using the Microsoft Access to accommodate the text, image and link the whole data. Microsoft Access was chosen consider that the software easy to provide in Indonesia. 


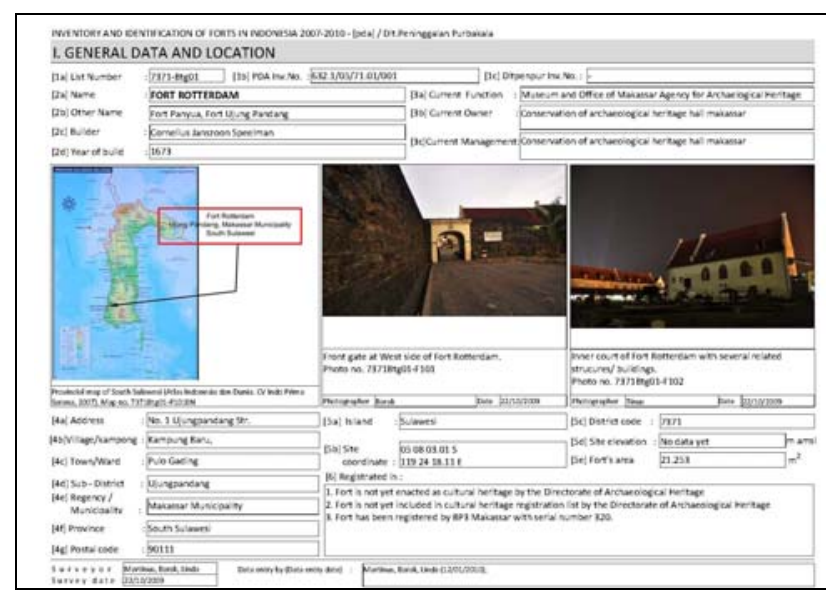

Figure 20. Inventory format of general data and location, in Microsoft Access

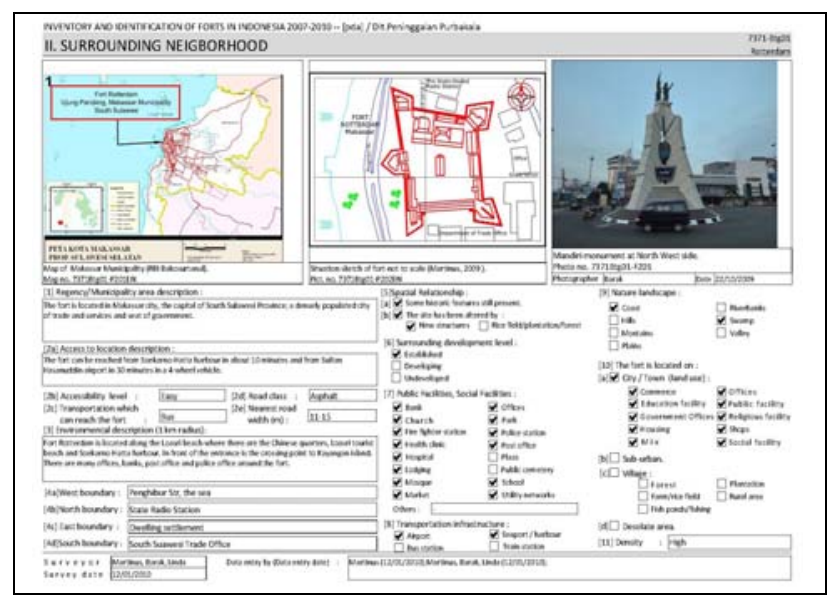

Figure 21. Inventory format of surrounding neighbourhood, in Microsoft Access

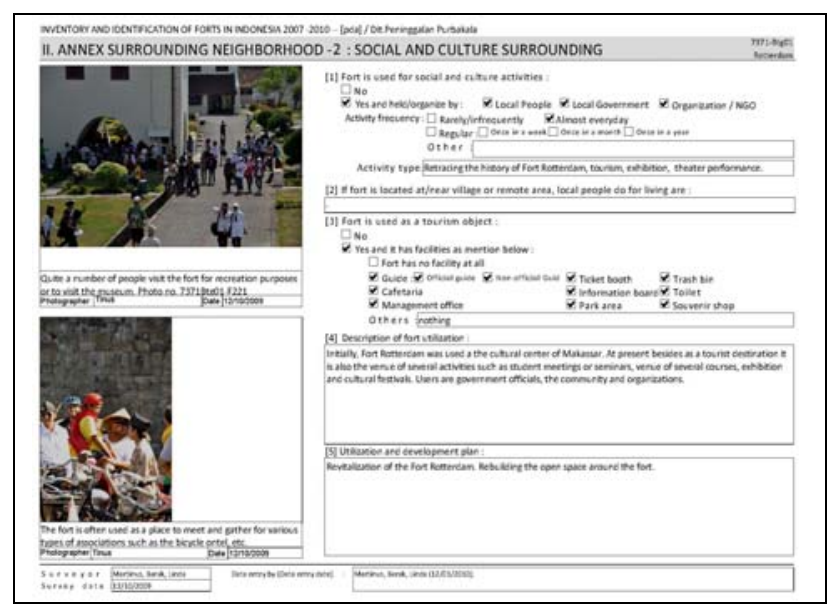

Figure 22. Inventory format of annex II: surrounding neighbourhood, in Microsoft Access

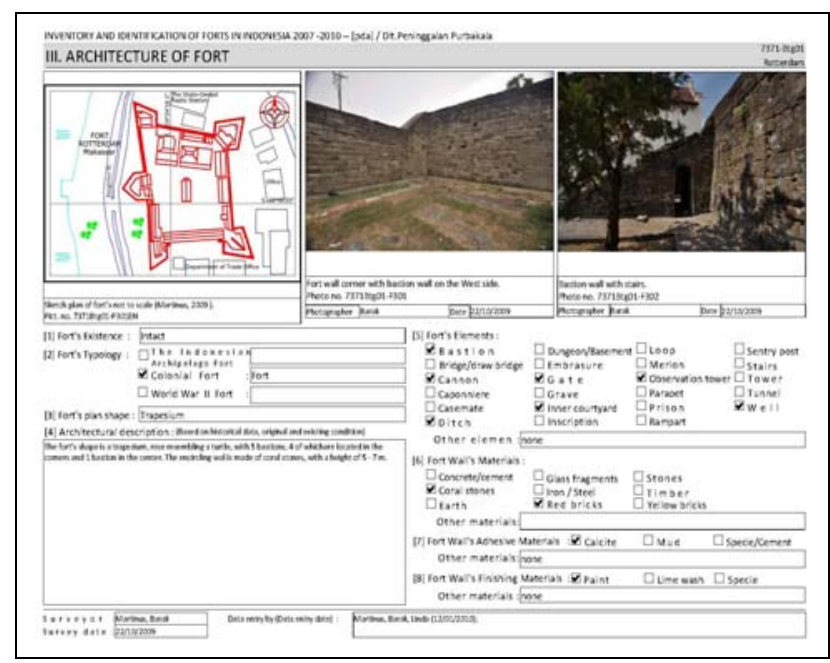

Figure 23. Inventory format of architecture, in Microsoft Access

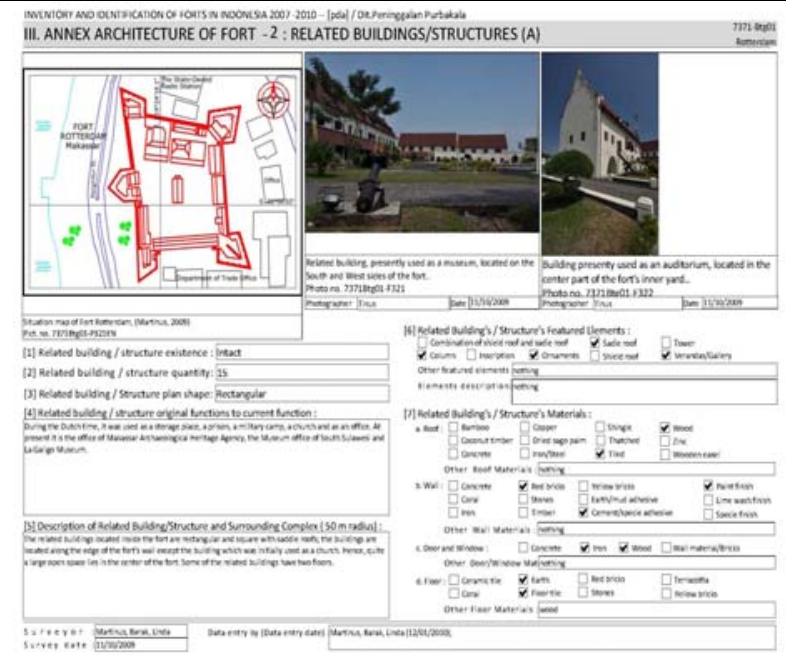

Figure 24. Inventory format of annex architecture: related buildings/structures, in Microsoft Access

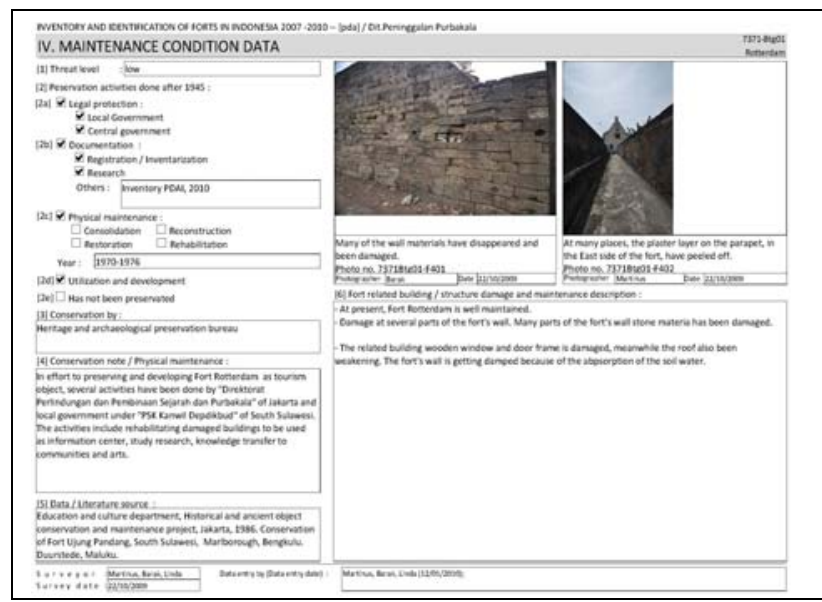

Figure 25. Inventory format of maintenance condition, in Microsoft Access. 


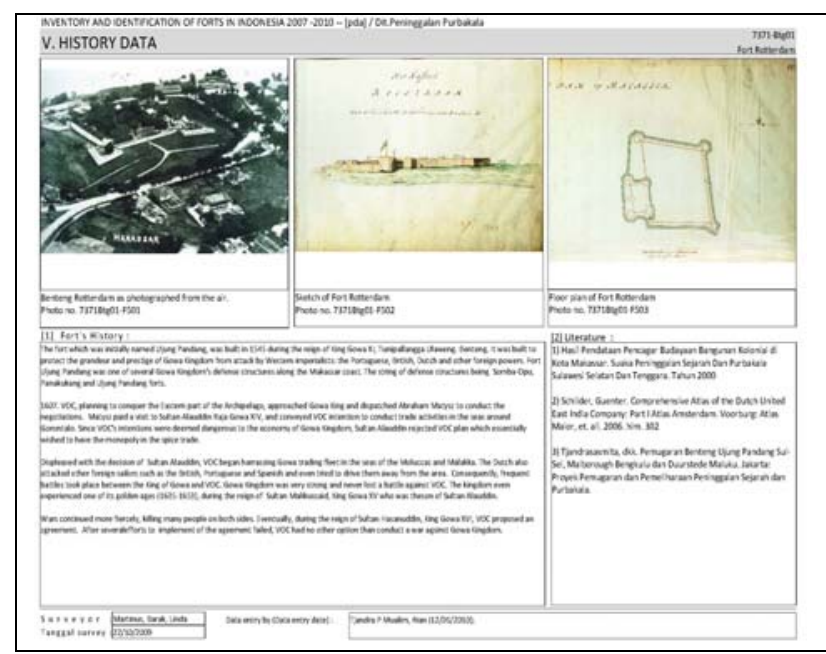

Figure 26. Inventory format of history, in Microsoft Access. The list of sources was written down for any further research uses

\subsubsection{Database Backup and Public Access}

As mentioned before, after the final verification of forts database by experts, it transferred to the web master, function as backup data and website that could be accessed by public (http://www.benteng-indonesia.org/). The database now was transferred and maintained under The Ministry of Education and Culture for further updating.

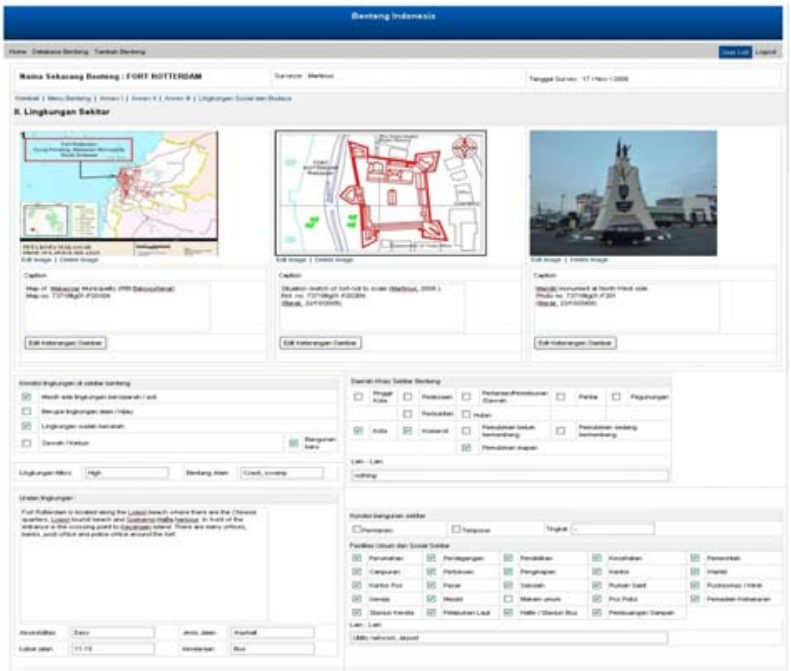

Figure 27. Display of web master, using the same layout of the Microsoft Access

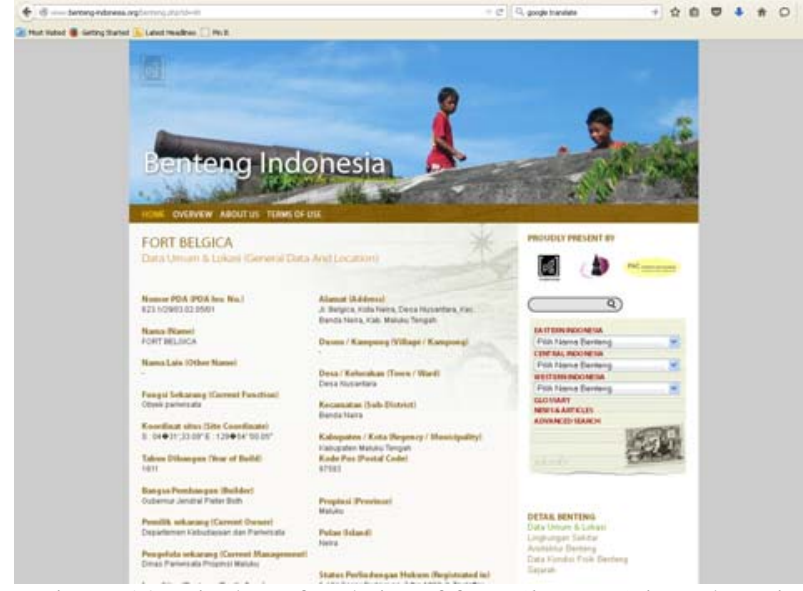

Figure 28. Display of website of forts (benteng) in Indonesia http://www.benteng-indonesia.org/

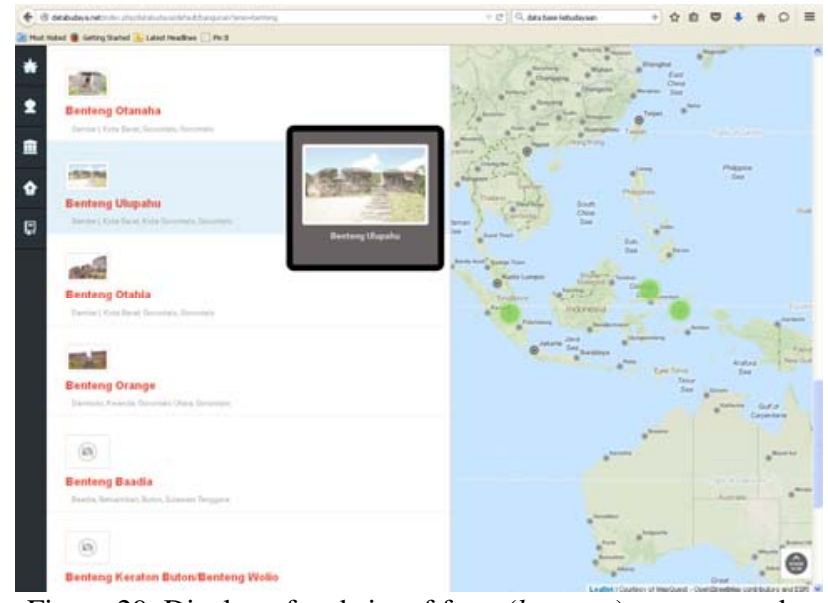

Figure 29. Display of website of forts (benteng) manage under The Ministry of Education and Culture (still under construction) http://databudaya.net/index.php/databudaya/default/bangunan?j enis=benteng

\section{CONCLUSIONS}

\subsection{Numbers of forts and its condition}

The results of inventory project was 442 forts has found and recorded, consist of 128 objects Nusantara Forts, 139 objects Colonial Forts and 175 sites WW I and II Defenses Structures/Systems. The conditions of 442 forts are 9 objects not exist, 64 objects remnant/destroyed, 143 objects damage/ruins, 226 objects intact.

\subsection{Legal protection status}

The numbers of forts that has legal protection status has increasing after the projects. Up to 2010 (end of project) there are 94 forts has listed and protected as cultural heritage under the National and Regional law.

\subsection{Forts Preservation and Development}

Proven as sustainable project, after the inventory the numbers of forts that have been preserved and developed was increase and many of them are still ongoing preservation project up to now. Using the database ranking system, combine with 
economic formulation, there are 60 forts have selected that have potential value to develop in the future. The preservation projects were executed under the Ministry of Education and Culture, Ministry of Public Works in collaboration with the provincial governments or municipalities. The sustainable values, were not only for database updating but more important was the multitude benefit for various preservation program such publications, exhibitions, scholars research and forts conservation projects for its adaptive re-use.

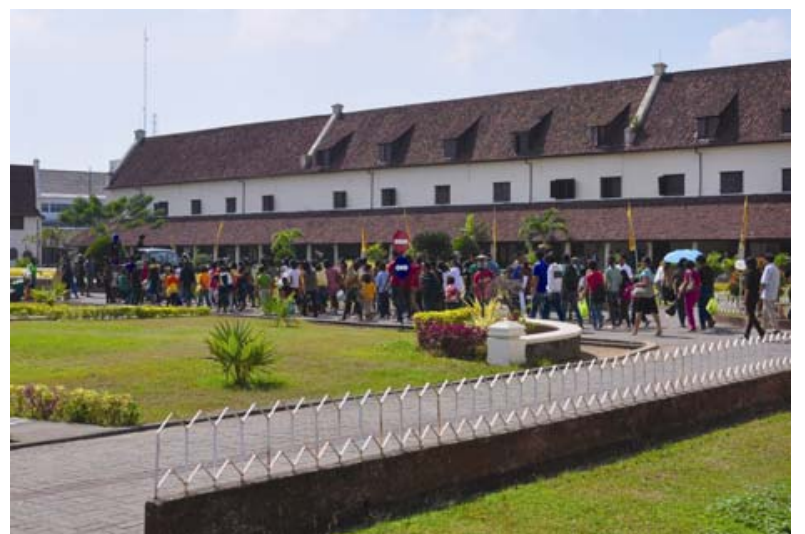

Figure 30. Fort Rotterdam in Makassar, Sulawesi, has preserved and used for public space and cultural events $\mathbb{C}$ Image

Copyright 2010, PDA

\subsection{Legal protection status}

The inventory format was proven very useful not only for this project. Ministry of Public Works adopts the inventory format for the heritage buildings inventory project of heritage cities in Indonesia since 2013. It has already hundreds of heritage buildings in 10 heritage cities in Indonesia have inventoried use this format.

\subsection{Database}

The project now continues to collaborate with the Netherlands, to develop the digital online archives of Atlas Mutual Heritage (http://www.atlasofmutualheritage.nl/).

\section{ACKNOWLEDGEMENTS}

Upon graduated as an architect in 1994, F. Suryaningsih and N. Purwestri has been active in inventory, documentation and research of heritage building and district, architecture exhibition, conservation of living monuments and publication. Both are of the co-founders of PDA, currently serves as Executive Directors of PDA (www.pda-id.org).

\section{REFERENCES}

Pusat Dokumentasi Arsitektur, 2010. Inventory and identification forts in Indonesia. Jakarta : Pusat Dokumentasi Arsitektur, Kementerian Kebudayaan dan Pariwisata, PAC Architects and Consultant.

Reid, Anthony, 1993. Southeast Asia in the Age of Commerce, 1450-1680, vol. II. Expansion and Crisis. New Haven: Yale University Press.
Valentijn, Francois, 1724. Oud en nieuw Oost-Indien, vervatiende een naaukeurige en uitvoerige verhandelinge van Nederlands mogentheyd in die gewesten, benevous eene wydluftige beschryvinge der Moluccos... Amsterdam : Gerard Onder de Linden.

Wall, Victor Ido van de and Oudheidkundige Dienst in Nederlandsch-Indie, 1930. Korte gids voor de Oud-Banten. Serang: G.J. Vos.

Wall, Victor Ido van de. 1929. Bouwgeschiedenis van het Fort Speelwijk te Banten. Weltevreden : Albrecht en Co..

Wall, Victor Ido van de. De Nederlandsche oudheden in de Molukken. s-Gravenhage : Martinus Nijhoff, 1928.

Abbas, Novida, 2001. Dutch forts of Java alocational study. Singapore : National University of Singapore.

Bleeker, Pieter, 1838. "Fragmenten eener reis over Java" in Tijdschrift voor Nederlandsch-Indie - Jrg. 1849, deel II and Jrg. 1850, deel I en II. Batavia : Ter Lands-drukkerij.

Pusat Dokumentasi Arsitektur, 2008. Final Report Inventory of Fort in Indonesia 2008. Jakarta : Pusat Dokumentasi Arsitektur, Kementerian Kebudayaan dan Pariwisata, PAC Architects and Consultant.

Pusat Dokumentasi Arsitektur, 2009. Final Report Inventory of Fort in Indonesia 2009. Jakarta : Pusat Dokumentasi Arsitektur, Kementerian Kebudayaan dan Pariwisata, PAC Architects and Consultant.

Pusat Dokumentasi Arsitektur, 2010. Final Report Inventory of Fort in Indonesia 2010. Jakarta : Pusat Dokumentasi Arsitektur, Kementerian Kebudayaan dan Pariwisata, PAC Architects and Consultant. 